\title{
Peter Salner
}

Ústav etnológie a sociálnej antropológie

Slovenská akadémia vied, Bratislava

(D) https://orcid.org/0000-0002-6844-0235

\section{Socialism and the Jewish Community in Slovakia*}

\begin{abstract}
This study is based on data acquired by the oral history method and discusses the reflections of two generations of Jews in relation to the socialist regime in Czechoslovakia (1948-1989).

The first generation is represented by people who had survived the Holocaust. The second generation is represented by the 'children of the Holocaust' (born 1945-1965). They grew up at a time when the political realm was completely dominated by the Communist Party. Their attitudes only changed with the invasion of Czechoslovakia in August 1968. This probe suggests differences which stem from contrasting life experiences.
\end{abstract}

Keywords: socialism, Jewish community, survivors, children of the Holocaust, emigration

Słowa kluczowe: socjalizm, społeczność żydowska, ocaleni, dzieci Holokaustu, emigracja

\section{Sources}

The study mostly utilises data that I have acquired by participating in two research projects aimed at the oral history method. ${ }^{1}$ The first was an international project initiated by Professor Geoffrey H. Hartman of Yale University, whose

* This paper emerged as part of the Slovak Research and Development Agency Project 16-0345, Contemporary Views of Socialism.

${ }^{1}$ It is not my aim to give a detailed account of the genesis, development, and theoretical aspects of the oral history method. I will content myself with saying that it uses audio or video to record the testimonies of people who have had a firsthand experience with a specific historical era or event. Researchers then use these recordings in their analysis of the subject matter. 
Slovak component was called "Oral History: The Fates of Those Who Survived the Holocaust." As the name suggests, the purpose of the project was to create a video repository of people's stories from the Shoah. All the recorded testimonies (including 148 from Slovakia) are stored in the Fortunoff Video Archive for Holocaust Testimonies, which is part of Yale University.

In Slovakia the project took place from 1995 to $1997 .{ }^{2}$ Converted to a text, the testimonies make up over 5,000 pages. Although the project was primarily focused on the Shoah, the interviewers also asked about the respondents' lives before the Second World War and during the socialist era. This study centres on people who at the time of Communism's rise in Czechoslovakia had already reached adulthood (meaning they were born before 1930). From the archive I have selected interviews which met the criteria of the study in terms of both quality and the age of the respondents.

I also use the oral history method in the ongoing Slovak Research and Development Agency Project 16-0345, Contemporary Views of Socialism. ${ }^{3}$ In this case, the interviews are focused on the children of the Holocaust, born between 1945 and 1960 (people who are in their sixties and seventies today). I have chosen the given age group because its representatives were educated at a time when the political realm was dominated by the Communist Party of Czechoslovakia (KSČ). During childhood and youth, many of them acquired the experience of "living with a mask." They knew that the regime was forcibly promoting an ideology that did not correspond to the private convictions, life experience, and shared narratives of a large part of the adult population. As a result, parents, Jewish and otherwise, often instructed their children to act differently in public than they did at home. One of the respondents reflected on this reality as follows:

Of course I didn't agree with the ideology. But we swallowed our pride and kept our mouths shut. I couldn't even imagine that it would ever end - that we would live in a different regime. (SOS, Man 1947B)

In the long term, this approach often resulted in the fact that "the mask, intentionally or not, became part of the person's identity. The wearer could not

${ }^{2}$ The Slovak testimonies are curated by the Milan Šimečka Foundation, which also coordinated the research project. For further details, see M. Bútora: Svedectvá o holokauste [Holocaust Testimonies]. In: IdEM: Druhý dych [Second Wind]. Bratislava 2010, pp. 394-425; P. SALNER: Svedectvo tých, ktorí prežili holokaust [The Testimonies of Those Who Survived the Holocaust]. „Slovenský národopis” 1995, vol. 43, pp. 445-460; P. SAlner: Prežili holokaust [They Survived the Holocaust]. Bratislava 1997; M. VRzGulová: Nevyrozprávané susedské histórie. Holokaust na Slovensku $z$ dvoch perspektív [Untold Neighbours' Histories: The Holocaust in Slovakia from Two Perspectives]. Bratislava 2016.

3 This study uses data from the first 20 interviews I carried out in Bratislava and Košice - cities with the most populous Jewish communities. 
and sometimes did not want to take it off even after the social and political strictures had disappeared."

In interpreting the opinions of the latter generation, I drew from one other important source apart from oral history, namely, the email correspondence that has been taking place since 2004 on the informal webpage Stretnutie (The Meeting), which was renamed as Svetlo (Light) in April 2009. The group was founded in 2004 by Jewish emigrants from Bratislava who had left the country after the August 1968 invasion of Czechoslovakia. ${ }^{5}$ Among the founders were people living in Australia, Canada, Israel, the USA, and different countries in Western Europe. Today the group has over 300 members who live in 18 countries across four continents. At the time of writing, the correspondence consists of more than 51,000 emails. Many of them deal with ethnologically interesting subjects such as emigration, adapting to life in a new environment, Jewish identity, antisemitism, but also memories of childhood and youth in socialist Czechoslovakia.

\section{The Jewish Community after the Liberation of Czechoslovakia}

After the liberation, members of the community had three options for their future:

1. Between 1945 and 1950, a number of religious communities, especially in smaller towns, disintegrated as a consequence of aliyah. ${ }^{6}$

2. A small part of the survivors stayed in Slovakia and maintained their faith and Judaist traditions. ${ }^{7}$ Even many of those who had abandoned their faith

${ }^{4}$ P. SALner: Život s maskou [Life with a Mask]. „Kultúrny život” 1993, Vol. 10, p. 6.

${ }^{5}$ From 1968 to 1971, 4,500 Jews emigrated from Slovakia (J.A. JeLÍneK: Dávidova hviezda pod Tatrami. Židia na Slovensku v 20. storoči [The Star of David under the Tatras. Jews in Slovakia in the 20th Century]. Prague 2009, p. 421). This amounted to over 50\% of the entire Jewish community at that time. Only a small number settled in Israel. The vast majority had left for countries across the pond (Canada, US, Australia). In Europe, most were drawn to Germany and Switzerland, where attitudes towards immigrants were the most agreeable (for more, see I. Bumová: Postoj ŠtB k emigrácii československých občanov v rokoch 1963-1983 (s dôrazom na Západoslovenský kraj) [The Attitudes of the Communist Secret Service to the Emigration of Czechoslovak Citizens in 1963-1983 (with an emphasis on Western Slovakia)]. In: E/Migrácie a Slovensko [E/Migration and Slovakia]. Ed. D. LuTHer. Bratislava 2006, pp. 41-74; I. Bumová: ŠtB a židovská mládež (na príklade Západoslovenského kraja $v$ rokoch 1969-1980) [The Communist Secret Service and the Jewish Youth (illustrated on the case of Western Slovakia in 1969-1980)]. In: Židovská komunita po roku 1945 [The Jewish Community After 1945]. Ed. P. SALNER. Bratislava 2006, pp. 67-100).

${ }^{6}$ See P. SALner: Židia na Slovensku po roku 1945 (Komunita medzi vierou a realitou) [Jews in Slovakia After the Year 1945: A Community Between Belief and Reality]. Bratislava 2016.

${ }^{7}$ Ibid. 
continued to feel part of the Jewish community, though not of its religious component. After the ban on civil associations (including Jewish ones) in $1950,{ }^{8}$ they had no other option apart from joining official religious communities. With their secular attitudes, they contributed to the gradual weakening of the communities' religious orientation (especially the Orthodox).

3. Another alternative was represented by the attempt at full assimilation, which was occasionally confirmed by baptism. The forms of the Jewish family had changed. ${ }^{9}$ After the liberation, incomplete forms prevailed. The survivors had to replace their original family members and recreate functioning family units. This resulted in many new endogamous and mixed marriages (which were often unequal in terms of age and social or religious circumstances), adoption of orphans, and also a large number of new-born children. In terms of form, these families did not differ too much from the wider society, although a more detailed analysis does reveal several distinctions. Most importantly, there is the disruption of intergenerational continuity, which resulted from the absence of grandparents, ${ }^{10}$ as well as from some survivors' decision to assimilate and others' decision not to burden their children with unpleasant stories and memories. ${ }^{11}$ As part of the strategy of forgetting many parents did not talk to their children about matters concerning Judaism, even going as far as to hide their ethnic origin from them. The children would only find out about their Jewishness (and about their family history) later in life, often under unpleasant and surprising circumstances:

When my son was in secondary school, he didn't know that he was a Jew. After all, his mother wasn't Jewish. One day, his classmates called him a 'filthy Jew.' He was so shocked and surprised by the discovery that he said he was proud of it. (OH, Man 1937)

These circumstances resulted in the fact that some of the children of the Holocaust did not know and even rejected Jewish traditions. From the perspective of the community, they represent a 'lost generation.'

${ }^{8}$ E. Mannová: Spolky v období sociálno-politických zmien na Slovensku 1938-1951. (Analýza spolkových stanov) [Civil Associations Between Political Changes in Slovakia 1938-1951 (Analysis of Federal Statues)]. In: Občianska spoločnost' na prahu znovuzrodenia [Civil Society on the Cusp of Rebirth]. Ed. J. StenA. Bratislava 1992, pp. 27-29.

9 For more, see P. SALner: Židia na Slovensku medzi tradíciou a asimiláciou [Jews in Slovakia Between Tradition and Assimilation]. Bratislava 2000; IDEm: Židia na Slovensku po roku 1945...

${ }^{10}$ Eva Umlauf recalls her sentiments (shared by other Jewish children) when her classmates travelled to spend summer holidays with their grandmas and grandpas: "[...] Because we had no relatives and certainly no grandmothers and grandfathers that we could visit” (E. UMLAUf, S. Oswalt: Die Nummer auf deinem Unterarm ist blau wie deine Augen. Erinnerungen. Hamburg 2016, p. 112).

${ }^{11}$ Parents did not talk to their children about 'improper' political subjects. That is why Jewish children were often quick to join the Pioneers and other youth organisations. What their parents and many of their peers - viewed as "living with a mask," they viewed as a natural expression of their worldview. 
In several cases, persisting fear of antisemitism led to baptisms of children born after the liberation.

I married a Catholic, and I have two daughters who were both baptised Catholic. I did that on purpose. I consider myself Slovak. My mother tongue is Slovak. I love this country, and I want to live here, but only as an equal citizen under the law. All that said, I've accepted the lesson of history - people never learn from their mistakes, and I don't want any of my descendants to go through what I had to go through. (OH, Man 1930)

My mother, a pure-blooded Jew, insisted that I baptise my son because you never knew when Hitler was going to come back, and being baptised could save my son's life. My daughter is baptised too. $(\mathrm{OH}, \text { Man 1912) })^{12}$

A great many Jews who had survived the Holocaust and stayed in Slovakia welcomed the new (and thus far unknown) regime. Some because they had left-leaning political tendencies during the interwar period; others because they wanted to express gratitude to the Red Army for the liberation. There was also a pronounced faith that Communism would be a guarantee of a better (and, more importantly, safer) future.

During the four decades of Communist rule, the regime underwent complicated developments, alternating between periods of repression (especially 1948-1956) and periods of gradual liberalisation (the 1960s). The latter period met its definitive end on August 21, 1968.

\section{The Times as Remembered by the Survivors}

Despite the time elapsed, the historical reality and atmosphere of the times find strong reflection in the memories of the survivors. The testimonies of most exude a positive expectation and a subsequent disillusionment. Here are several illustrative examples:

I was young. I was happy that we had survived the war and excited that we would finally have Communism. (OH, Woman 1920)

I had imagined, dreamed of the Soviet Union as a kind of promised land. Besides that, I was just very grateful, like many people who had taken part in the Uprising - antifascists and not all of them Jews... I was thankful to the Soviet Union for the liberation. (OH, Man 1916)

Because I had been a partisan (antifascist militiaman) during the Uprising, I later joined the Communist Party. I thought of the Soviets as our liberators and viewed them as the solution. Most

${ }^{12}$ In both cases, the baptisms took place in the 1950s and brought the families into the crosshairs of the ruling regime. The parents were, nevertheless, more fearful or going back to the past than they were of the contemporary threats. 
of us were later disillusioned, but it's undoubtable that we'd been quite hopeful in the beginning. (OH, Man 1924)

The change in attitude was especially manifest after the show trials of the 1950s.

It got even worse after the war, when people who had been on my side - or at least I thought they had; people with whom I had fought for socialism - suddenly began to view me as untrustworthy. They persecuted me because I had a different opinion and because I was Jewish. Despite all that talk of internationalism, Jews had suddenly become untrustworthy. It was very painful. During the war I knew that the enemy was right in front of me, but now they were all around, behind my back. My own comrades had turned on me. (OH, Man 1923A)

The following testimony of a pre-war member of the Communist Party of Czechoslovakia illustrates that the attitude shift represented a difficult and often painful process:

I would end by saying that I cannot conceive how someone can became a turncoat overnight how they can go from being a Communist to being an anti-Communist or a nationalist or whatever; from being an atheist to being religious. My political transformation took a long time, and here I must paraphrase the Israeli writer Ephraim Kishon, who said that in Israel, parents learnt Hebrew from their children. I never learnt Hebrew, but my wife and I certainly became ardent anti-Communists thanks to our sons. (OH, Man 1923B)

\section{The Times as Remembered by the Subsequent Generation}

Children born shortly after the liberation grew up in the Communist regime, but they encountered Nazism, too, particularly through the physical and mental consequences suffered by their parents, as well as through the parents' talk of (or silence about) ${ }^{13}$ the Holocaust.

Both my parents were Holocaust survivors. They had both been in concentration camps. My father came back, but his health was very frail. He lived to be sixty-five and then died. My mother lived longer. But both of them had carried the trauma for their entire lives. And so they told me - especially my mother - about the tribulations they had gone through. (SOS, Man 1947)

This phenomenon had an even greater effect on another respondent:

My mother's health wasn't very good. Her eyesight came back after the stress and fear had passed. Fear is the worst thing a human being can experience. Fear for oneself, fear for one's children... So my mother's eyesight had come back, and she was in an adequate condition - she could function

${ }^{13}$ For more on the phenomenon of talking vs. silence in families, see P. SALNER: Hovorit? Mlčat? [To Talk or to Remain Silent?]. In: M. VRzgulová, L. Volanská, P. SAlner: Rozprávanie a mlčanie [Talking and Silence]. Bratislava 2017, pp. 86-109. 
normally, but I must say that she was very depressive for her whole life. And in my father and us, the kids, that created a curious reaction, which I think is familiar to every Jewish child - when you start taking care of your parent. (SOS, Woman 1948)

The children of the Holocaust only knew about the Shoah via second-hand testimony, but when it came to Communism, they could view and assess it based on their own experience. Thanks to the 'protection' availed to them by their parents, many of them had a calm childhood. They came to identify with the official ideology because they knew no alternative. They were active in the Pioneers or in other youth movements, and the negative aspects of the era only had a marginal effect on them.

Where's that picture of the synagogue on Pushkin Street? I used to go to school there, to the neighbouring building, the former Jewish school. The synagogue and the school had a shared yard. In second grade, one of my teachers asked me to write down a list of people who attended the temple during holidays, because I knew them. (Light, Woman 1947, London)

People whose parents were persecuted or imprisoned by the regime had a very different perspective.

I would visit my father in prison, whether in Příbram, in Leopoldov, or elsewhere. But only several years later after hed been taken away. In the beginning we didn't even know if he was alive. One day, my father touched my pinkie through the screen mesh, and he was put in solitary confinement and barred from all contact with his family. That's just a tiny detail. Other than that, everyone can read my mother's memoir. I really recommend it, though it might sound strange, coming from a daughter. (Light, Woman 1948, Sweden) ${ }^{14}$

Only when the children of the Holocaust were teenagers did they adopt a more critical attitude towards the regime (especially thanks to the information they acquired throughout the 1960s, and because of the shock of the August 1968 invasion). They expressed it when reflecting on the era of normalisation (1970-1989):

What did I dislike about the regime? Everything, really. I disliked that I couldn't express my opinion in public and that I had to lead a double life of sorts. I don't want to say schizophrenic, because schizophrenia is about something else... But there were certain things that I couldn't talk about even with my closest non-Jewish friends. They just weren't appropriate subjects for discussion. (SOS, Woman 1951A)

When I was growing up, it was a very hypocritical era. Everyone was ashamed of being Jewish. Even as kids, we were ashamed. My parents, or my mother, they had been afraid, but we were ashamed. (SOS, Many 1947C)

${ }^{14}$ The book in question is the memoir of Jo Langer. In the book she described how she and her two little children lived after her husband had been imprisoned. The original title of the book (J. LANGeR: Vtedy v Bratislave. Môj život s Oskarom L. Bratislava 2007) is Convictions: My Life with a Good Communist. 
Socialism had sucked everything Jewish out of us. (SOS, Woman 1951B)

The only upside was that we all got guaranteed jobs after graduation. We had work and we could start a family without any trouble. The downside was that we were oppressed. We couldn't travel and we couldn't uphold religious traditions. Nobody would've dared to publicly say that they'd gone to the cheder, to the synagogue, or that they observed Jewish holidays. All of that had to be done in secret. (SOS, Man 1947B)

\section{Emigration}

A key moment in the lives of many representatives of the latter generation was the invasion of Czechoslovakia in August 1968. As many times before, the 'Jewish Hamletic dilemma' - to stay or to leave - suddenly became all too relevant: "We talked about emigration every day" (SOS, Woman 1948). In some cases entire families opted to leave the country. In others, only individuals. The complicated decision process is illustrated by the following email:

Fifty years ago today, we returned from Israel after volunteering at the Lehavot Haviva kibbutz. In 1968, the question of going back to Czechoslovakia posed a dilemma between freedom on one hand and family, more specifically parents, on the other: should we stay in Israel and resist their plea to COME BACK? Many were fortunate in that their parents encouraged them to stay, and they stayed. Others returned, as well-behaved children were expected to do. Today we can look back at what it was like. What it was like in 1968 and in the ensuing years. What it was like in Czechoslovakia, in Israel, in Germany, in Switzerland, and in other countries. We can reflect on how we experienced our first and subsequent years abroad. We can think about what those years brought us and what we lost, wherever we happened to be. Because each of us sacrificed something in our decision, at least for a time. (Light, Man 1948, Bratislava)

The email inspired an immediate reaction:

Like you say, Peter, "many were fortunate." Yes, everyone dealt with the situation as best they could. My parents, for example, had survived the Holocaust. They had also survived persecution from the antisemitic Communist regime. Hence, they decided that they weren't going to make the same mistake as in 1949, when they still could've left and didn't. They made our decision for us, their good children, so we wouldn't have to return to the Communist "paradise." And, thank God, the decision they made was the right one. (Light, Man 1942, Zurich)

\section{A similar approach is evident in another family:}

My parents spent their entire lives regretting that they hadn't left after the war. So they were supportive of my staying abroad. They didn't want me to "miss that train." (Light, Woman 1947, London)

At the time, emigration was a popular option with the young and middleaged generations. Their decision was influenced by the fact that the children of 
the Holocaust, "because of their relatively cosmopolitan education, better grasp of foreign languages, and greater familiarity with the West, did not view emigration as such a horrifying prospect." ${ }^{\prime 5}$ Also, important were the welcoming attitudes of the Western countries, the support of Jewish organisations, and the fact that many Jews had close relatives and friends abroad. People who chose to emigrate in the 1980s faced a more difficult situation:

Would I have emigrated again with the benefit of hindsight? I certainly would've thought about it more. In Czechoslovakia I had been chief of the planning department. We weren't drowning in money, but compared to others, we lived a rather decent life. We couldn't travel to the West, and there were also other constraints, but we knew that's just how it was. And then you emigrate, and everyone looks down on you, you know. I still have an accent to this day. Back then I had an even stronger accent and I didn't understand as much, so people mocked and laughed at me. They said there was no way I was really an engineer. (SOS, Man 1947C)

\section{Conclusion}

This probe into the Jewish community has shown that the two generations under consideration mostly differ in terms of life experience, which was also evident during the research. The survivors had lived in the democratic First Czechoslovak Republic. They had known vibrant religious associations and, most importantly, they had endured the tragedy of the Shoah. Due to the differences in age and experience, they displayed a certain sense of superiority in their interaction with the researcher. In the case of the children of the Holocaust, who were the author's peers and, therefore, had a similar experiential background, the interviews were rather more equal.

Generationally-conditioned differences were also obvious in the respondents' reflections on the Communist era. The survivors who had stayed in Slovakia welcomed the new regime in 1948 with the hopes for a better and, what was more significant, safer future. All the greater was their disillusionment with the blatant antisemitism (often disguised as 'anti-Zionism'), which emerged during the show trials at the dawn of the 1950s. The survivors' memories evince great emotion but also a gradual shift away from their initially positive expectations.

The generation of the children of the Holocaust grew up in the socialist regime and was subjected to intense Communist propaganda. Until the 1960s, most of them could not compare the situation in Czechoslovakia with conditions in the interwar period or in contemporary democracies. In families where the official ideology ran counter to the opinions of the adults, the parents often

15 A. Heitlingerová: Ve stínu holocaustu a komunismu. Čeští a slovenští židé po roce 1945 [In the Shadows of Communism and the Holocaust. Czech and Slovak Jews since 1945]. Prague 2007, p. 139. 
kept their convictions secret from their children. They either did not talk about politics or spoke in a different language, which their children could not understand. Alternatively, they brought them up to "live with a mask."

This study has highlighted a spectrum of opinions regarding the potential positive and negative aspects of the socialist regime. While some of the respondents' reflections were coloured by rosy retrospection, others showed a more critical attitude. The positive aspects of the era, the most dominant of which was social security, were clearly outweighed by the negative ones, including religious persecution, limited freedom of movement, and various other forms of repression. The testimonies reveal a significant difference between people whose families were directly victimised by the state apparatus (these mostly opted for emigration after 1968) and those who lived in relative calm.

\section{Bibliography}

Bumová I.: Postoj ŠtB k emigrácii československých občanov v rokoch 1963-1983 (s dôrazom na Západoslovenský kraj) [The Attitudes of the Communist Secret Service to the Emigration of Czechoslovak Citizens in 1963-1983 (with an emphasis on Western Slovakia)]. In: E/Migrácie a Slovensko [E/Migration and Slovakia]. Ed. D. Luther. Bratislava 2006, pp. 41-74.

Bumová I.: ŠtB a židovská mládež (na príklade Západoslovenského kraja v rokoch 1969-1980) [The Communist Secret Service and the Jewish Youth (Illustrated on the Case of Western Slovakia in 1969-1980)]. In: Židovská komunita po roku 1945 [The Jewish Community after 1945]. Ed. P. SALnER. Bratislava 2006, pp. 67-100.

Bumová I.: Protižidovské výtržnosti v Bratislave $v$ historickom kontexte [Anti-Jewish Riots in Bratislava in a Historical Context]. „Pamät národa” 2007, Vol. 3, III, pp. 14-29.

Bútora M.: Svedectvá o holokauste [Holocaust Testimonies]. In: IDEM: Druhý dych [Second Wind]. Bratislava 2010, pp. 394-425

Epstein H.: Děti holocaustu [Children of the Holocaust]. Prague 1994.

Heitlingerová A.: Ve stínu holocaustu a komunismu. Čeští a slovenští židé po roce 1945 [In the Shadows of Communism and the Holocaust. Czech and Slovak Jews since 1945]. Prague 2007.

JавLONкová Ch.: Izrael a Židia zo Slovenska [Israel and Jews from Slovakia]. In: „Acta judaica Slovaca" 1998, Vol. 4, pp. 163-186.

Jelínek J.A.: Dávidova hviezda pod Tatrami. Židia na Slovensku v 20. storoči [The Star of David under the Tatras. Jews in Slovakia in the 20th Century]. Prague 2009.

Kamenec I.: Po stopách tragédie [On the Trail of Tragedy]. Bratislava 1991.

Kováč D.: Dějiny Slovenska [History of Slovakia]. Prague 1998.

Lexikón slovenských dejín [Lexicon of Slovak History]. Bratislava 1997.

LANGer J.: Vtedy $v$ Bratislave. Môj život s Oskarom L. [Convictions: My Life with a Good Communist]. Bratislava 2007.

Mannová E.: Spolky v období sociálno-politických zmien na Slovensku 1938-1951 (Analýza spolkových stanov) [Civil Associations between Political Changes in Slovakia 1938-1951 (Analysis of Federal Statues)]. In: Občianska spoločnost' na prahu znovuzrodenia [Civil Society on the Cusp of Rebirth]. Ed. J. Stena. Bratislava 1992, pp. 21-30.

MešŤAn P.: Antisemitizmus v politickom vývoji Slovenska (1989-1992) [Antisemitism in the Political Development of Slovakia (1989-1992)]. Bratislava 1999. 
Mlynári J.: Dějiny Židio na Slovensku [History of Jews in Slovakia]. Prague 2005.

SAlner P.: Život s maskou [Life with a Mask]. „Kultúrny život” 1993, Vol. 10, p. 6.

SALner P.: Svedectvo tých, ktorí prežili holokaust [The Testimonies of Those Who Survived the Holocaust]. „Slovenský národopis” 1995, Vol. 43, pp. 445-460.

SAlner P.: Prežili holokaust [They Survived the Holocaust]. Bratislava 1997.

SAlner P.: Židia na Slovensku medzi tradíciou a asimiláciou [Jews in Slovakia Between Tradition and Assimilation]. Bratislava 2000.

SALner P.: Budúci rok v Bratislave alebo stretnutie [Next Year in Bratislava or a Meeting]. Bratislava 2007.

SAlner P.: Minulý rok v Jeruzaleme [Last Year in Jerusalem]. Bratislava 2010.

SAlner P.: Židia na Slovensku po roku 1945 (Komunita medzi vierou a realitou) [Jews in Slovakia After the Year 1945: A Community Between Belief and Reality]. Bratislava 2016.

Salner P.: Hovorit? Mlčat? [To Talk or to Remain Silent?]. In: M. VRzgulová, L. VolansKá, P. SAlner: Rozprávanie a mlčanie [Talking and Silence]. Bratislava 2017, pp. 86-109.

Sčítání lidu v v republice československé ze dne 1. prosince 1930, part I [The Czechoslovak National Census, 1 December 1930, Part I]. Prague 1934.

SLÁNSKÝ R.: Proces s vedením protištátneho sprisahaneckého centra na čele s Rudolfom Slánskym [Trial of the Anti-State Conspiracy Centred Around Rudolf Slánský]. Bratislava 1953.

Umlauf E., Oswalt S.: Die Nummer auf deinem Unterarm ist blau wie deine Augen. Erinnerungen. Hamburg 2016.

Vrzgulová M.: Nevyrozprávané susedské histórie. Holokaust na Slovensku $z$ dvoch perspektív [Untold Neighbours' Histories: The Holocaust in Slovakia from Two Perspectives]. Bratislava 2016. 